\title{
Urban Retail in Inland Abruzzo: Between Decline and New Polarities
}

Citation: B. Cardinale, D. Di Matteo, C. Pascetta, L. Zarrilli (2020). Urban Retail in Inland Abruzzo: Between Decline and New Polarities. Bollettino della Società Geografica Italiana serie 14 , 3 Special Issue: 81-92. doi: 10.36253/ bsgi-993

Copyright: (c) 2020 B. Cardinale, D. Di Matteo, C. Pascetta, L. Zarrilli. This is an open access, peer-reviewed article published by Firenze University Press (http://www.fupress.com/bsgi) and distributed under the terms of the Creative Commons Attribution License, which permits unrestricted use, distribution, and reproduction in any medium, provided the original author and source are credited.

Data Availability Statement: All relevant data are within the paper and its Supporting Information files.

Competing Interests: The Author(s) declare(s) no conflict of interest.

For Italian evaluation purpose: $B$. Cardinale responsability for section 1, D. Di Matteo for sections 3 and 4, C. Pascetta for section 2, L. Zarrilli for sections 5 and 6 .

\section{Il commercio urbano nell'Abruzzo interno: tra declino e nuove polarità}

\author{
Bernardo Cardinale ${ }^{1}$, Dante Di Matteo ${ }^{2}$, Concettina Pascetta ${ }^{3}$, Luca \\ ZARRILLI $^{4}$ \\ ${ }^{1}$ Facoltà di Scienze Politiche, Università di Teramo, Italy \\ ${ }^{2}$ Dipartimento di Architettura e Studi Urbani (DAStU), Politecnico di Milano, Italy \\ ${ }^{3}$ CRESA - Centro Studi Agenzia per lo Sviluppo della Camera di Commercio del Gran \\ Sasso d'Italia, L'Aquila, Italy \\ ${ }^{4}$ Dipartimento di Economia (DEc), Università degli Studi “G. d’Annunzio" di Chieti- \\ Pescara, Italy \\ E-mail: bcardinale@unite.it; dante.dimatteo@polimi.it; concettina.pascetta@libero.it; \\ luca.zarrilli@unich.it
}

\begin{abstract}
The multiple geographies of trade in Abruzzo reflect the heterogeneities of regional fabric itself: different constituents like orography, business demography, population density and infrastructure endowment have led to a two-speed growth of the retail sector, where coastal areas have developed faster than inland areas. Through retailers' and consumers' prism, this paper offers a focus on the urban retail in some cities of the inland Abruzzo, providing some policy implications. Availing of descriptive and semi-parametric approaches, we found that some public policies, like subsides and pedestrianisation, had an impact on retailers' perception based in inland areas even higher than those localised in coastal areas, while other features still remain lacking, such as accessibility; besides, compared with coastal areas, consumers' perceptions in inland areas show an higher social function, where buying behavior is less hedonic and more functional to the needs of local communities.
\end{abstract}

Keywords: Inland Abruzzo, urban trade, retailers' perceptions, consumers buying behavior.

Riassunto. Le molteplici geografie del commercio in Abruzzo riflettono l'eterogeneità dello stesso tessuto regionale: varie costituenti come l'orografia, la demografia d'impresa, la densità di popolazione e la dotazione infrastrutturale hanno causato una crescita del settore del commercio a due velocità, in cui le aree costiere hanno conosciuto uno sviluppo più rapido rispetto alle aree interne. Attraverso la lente dei commercianti e dei consumatori, questo articolo offre uno sguardo alle politiche urbane del commercio in varie città dell'Abruzzo interno, fornendo alcune implicazioni politiche. Mediante approcci descrittivi e semi-parametrici, troviamo che alcune politiche pubbliche, come le agevolazioni e la pedonalizzazione, hanno avuto un impatto maggiore sulle percezioni dei commercianti situati nelle aree interne rispetto a quelli localizzati nelle aree costiere, mentre altri aspetti rimangono carenti, come l'accessibilità; inoltre, rispetto 
alle aree costiere, le percezioni dei consumatori nelle aree interne sembrano mostrare una funzione sociale più consistente, laddove il comportamento d'acquisto è meno edonico e più funzionale alle esigenze delle comunità locali.

Parole chiave: Abruzzo interno, commercio urbano, percezioni dei commercianti, comportamento d'acquisto dei consumatori.

\section{Introduction}

In the early post-war decades, retail in Abruzzo experienced high levels of pulverisation due to its role as a refuge sector. With particular reference to the inland areas, sparsely populated and difficult to reach, local retail played a key social function, just satisfying the demand for essential goods of many mountain centres. The trade law reform (426/1971), which was supposed to ensure a productivity recovery in the trade sector encouraging the spread of large-scale distribution throughout the country, in Abruzzo region led to a leopard spot modernisation process (Landini 1981). In the coastal area - first in Pescara's provincial capital, then in neighboring municipalities - the establishment of large retailers faster occurred (i.e., supermarkets and large warehouses), while in inland areas, frequently characterized by a long-term population decline, only few urban trade polarities arose (L'Aquila, Sulmona, Teramo) where the large distribution remained weak. It is only in the decades straddling the new millennium that further suburban shopping centres were built in the proximity of motorway exits (Pratola Peligna) or along dual carriageways (San Nicolò a Tordino), thus succeeding in capturing the consumption demand of additional smaller communities (Scorrano 1997).

Such malling phenomenon was particularly visible in the city of L'Aquila, where the 2009 earthquake caused the relocation of many retailers in out-of-town shopping centres and galleries, which played a pivotal aggregating role for the suffering local community immediately after the health emergency. It has emerged a gap between the major urban cities of inland Abruzzo, where several suburban shopping centres has opened and the modernisation of the retail network finally occurred, and the other smaller municipalities of inland Abruzzo, where small retailers are called upon to meet only a neighborhood demand, which is even thinner in the case of the seismic crater area.

On such bases, this research explores the trade growth dynamics of inland Abruzzo always in comparison with the trend of coastal area. Broadly, this contribution is composed of six-parts: the introduction is fol- lowed by a reconstruction of trade-evolutionary dynamics in Abruzzo region from the early 1950s to nowadays, explaining the weight of the trade firms' demography over the resident population in the selected cities of the case study; instead, Sections three and four explore the perceptions of retailers in relation to some of the main trade policies: firstly, a correlation analysis was performed to individuate the main linkages between trade policies and retailers' degree of satisfaction; secondly, a linear model was used to evaluate to what extent the most relevant public policies have impacted on the degree of trade evolution of the four interested areas and through a semiparametric predictive model the features of retailers that primarily would need further targeted public interventions are identified; Section five exploits descriptive statistics to deepen the consumers buying behavior and data are retrieved from the early questionnaire used in Fuschi and Ferrari (2019); the last Section discusses the main findings in the view of the existing literature and provides conclusions and policy recommendations.

\section{Trade in inland areas, a diachronic reading}

Many studies have investigated the spatial patterns of retail distribution and have identified three consolidated trends in retail development: dichotomy between (i) coastal and inland areas, (ii) urban and rural ones, (iii) bigger and smaller urban centres. These trends have been recognized at different geographical scale: at national scale according to the studies regarding, for instance, Netherlands (Borchert 1988), Britain (Hallsworth 1994), India (Sinha, Kar 2007), Czech Republic (Szczyrba 2010), Brazil (Giraldo Lozano 2015), at regional scale regarding some Italian regions such as Marche (Porto, 2019), Piedmont (Brunetta 2007, 2011) or Sicily (Cannizzaro 2019) and at subregional scale, where examples come from Amiata area (Preite 2005), Assago area (Morandi, Paris 2013), Milan metropolitan area (Clerici 2019), Pesaro-Urbino province (Musso 2007, 2010) and Trentino (Brunetta, Caldarice 2016).

Keeping in mind the three mentioned trends, the analysis of commercial system in Abruzzo has been carried out using firstly baseline statistical indicators which have been already proposed, for instance, in some retail studies by Istat (Cozzi 2006). The retail system of four cities of inland Abruzzo has been analysed (L'Aquila, Teramo, Sulmona and Castel di Sangro), using the data made available by the Istat industry censuses since the second post-war period (1951-).

The current retail structure of inland areas is the result of the sedimentation of specific events to which 
local repercussions of global and national phenomena, as well as policies carried out by public bodies, have overlapped. The evolution of their retail system is different not only from that of coastal areas, because of specific demographic and economic trends, but also from that of the other settlements of inland Abruzzo, because the four analysed cities play important administrative or gravitational roles.

In 1951, the commercial structure of Abruzzo was dominated by Pescara, with regard to retail and to wholesale trade, although the demographic size of the latter was only slightly higher than that of L'Aquila, the regional capital, which was the second main distribution centre in Abruzzo and the main one in inland areas, due to its rising administrative functions. The number of residents served by each shop in inland areas was relatively limited and lower than the regional average, because of the small size of the population and the difficulties in mobility and transportation. This situation therefore necessitated a very scattered commercial distribution. The typical retail firm was predominantly family-run and had a low average number of employees. In inland areas, they were larger than in other parts of Abruzzo because they were able to draw customers from the neighbouring small towns. During the 1950s, the growth of the commercial structure of the four cities under investigation was considerable, both in retail shops supported by the population growth - and in wholesale shops, thanks to the role of trade as a safe-haven sector for agriculture and craft workforce not yet absorbed by the industry. Thus, a further pulverisation of the retail distribution structure occurred, along with the drop of the average number of inhabitants served by each firm.

In 1961, itinerant commerce in inland Abruzzo was still an important retail distribution sector, much more than the regional average, which is a proof of the rooted purchasing habits of the inland population. During the 1960s, the growth of inland Abruzzo distribution system slowed down: the lack of barriers to entry, which favored the access of entrepreneurs not keen on innovation, perpetuated a certain inefficiency.

Then, in 1971, L'Aquila kept on being the second main distribution centre after Pescara, with a number of inhabitants served by each retail shop that was still higher than the regional average: in Abruzzo region as a whole, indeed, retail shops were widespread due to the diffusion of small towns, where small shops guaranteed the minimum level of quality of life and the satisfaction of the primary needs of the inhabitants. During the 1970s, while the trade law reform (Law 426/1971) promoted the spread of modern distribution with department stores and supermarkets, the regional retail struc- ture was still fragmented and provided a traditional and backward supply. During this decade the population increased in our four cities and extra moenia development started close to the historical city centres through the creation of new peripheral neighborhoods along the main roads and near the industrial areas. The demographic increase encouraged the growth of the distribution sector, both wholesale and retail, along with a further decrease of the number of inhabitants served by each firm. Meanwhile, as nationally, food retail decreased due to the competition of large retailers, different eating habits and fewer restrictions on access to non-food retail markets.

In the 1980s, the population increase was still increasing thanks to the establishment of planned industrial areas (L'Aquila, Sulmona, Teramo), which attracted residential settlements and commercial activities along the connection roads. While wholesale stores kept on growing, retail stores decreased for the first time, while their average size increased. These are the first signs of the crisis of traditional retail that continued in the 1990 s, in line with the national trend and the contemporary growth of specialised retail.

At the beginning of the new millennium, the retail structure of inland areas had a lower level of modernisation compared to the Pescara's area, as proven by the absence of shopping centres, even in larger cities like L'Aquila and Teramo, and by the presence of just few department stores.

The 2009 earthquake dramatically hit L'Aquila's economy, which was mainly based on public administration, commercial firms and building companies. The physical destruction of the historic city centre forced the population, as well as the administrative, productive and commercial activities to leave. The resident population moved to the suburbs or to nearby towns, several firms had to close, and many other businesses moved to peripheral locations or in shopping centres and galleries. This phenomenon was a real push to malling, in contrast to the national and international trends, since the shopping centres played a renewed social role as aggregation poles and reference points for the community (Pascetta 2019, 43).

The current situation in inland cities, analysed by means of ASIA archive (the business register of local units by Istat), in 2017 shown a lower presence of trade firms compared to the urban area of Pescara and to the Abruzzo region as a whole, as a result of a drop in both retail and wholesale shops if compared to the previous two decades. As highlighted by the increase in the average size of trade firms, the role of large retailers has strengthened thanks to the opening of important shop- 
Table 1. Trade firms and inhabitants per trade firm in the selected cities and Abruzzo. Years 1951-2017. Source: author's elaboration on data from ISTAT Censuses and ISTAT ASIA Archive.

\begin{tabular}{ccccccccccc}
\hline & \multicolumn{2}{c}{ L'Aquila } & \multicolumn{2}{c}{ Sulmona } & \multicolumn{2}{c}{ Castel di Sangro } & \multicolumn{2}{c}{ Teramo } & \multicolumn{2}{c}{ Abruzzo } \\
\cline { 2 - 10 } & Firms & Inhab. & Firms & Inhab. & Firms & Inhab. & Firms & Inhab. & Firms & Inhab. \\
\hline 1951 & 653 & 83,7 & 314 & 72,6 & 80 & 67,9 & 424 & 91,1 & 12.656 & 100,9 \\
1961 & 985 & 56,9 & 556 & 38,5 & 127 & 40,2 & 844 & 49,6 & 20.040 & 60,2 \\
1971 & 1.169 & 51,4 & 547 & 37,7 & 163 & 31,0 & 1.008 & 47,4 & 26.668 & 43,7 \\
1981 & 1.419 & 44,9 & 665 & 35,7 & 243 & 21,4 & 1.199 & 42,6 & 32.356 & 37,6 \\
1991 & 1.408 & 47,5 & 715 & 35,6 & 232 & 23,6 & 1.241 & 41,7 & 32.365 & 38,6 \\
2001 & 1.424 & 48,1 & 745 & 34,0 & 219 & 25,7 & 1.189 & 42,9 & 30.847 & 40,9 \\
2011 & 1.297 & 52,0 & 664 & 36,8 & 195 & 30,5 & 1.193 & 45,4 & 30.053 & 43,5 \\
2017 & 1.259 & 55,2 & 601 & 40,2 & 196 & 34,2 & 1.117 & 48,6 & 28.039 & 46,9 \\
\hline
\end{tabular}

ping centres in the four cities concerned, which testifies an ongoing process of modernisation, although lagging behind if compared to the coastal areas.

Ten years after the earthquake, reconstruction in L'Aquila is still in progress. The municipality has carried out economic support initiatives, but still few firms - mostly restaurants and bars - have returned to the historic city centre. As against the pre-earthquake period there has been a decline in groceries and shops for personal items, as well as a loss of customers because people mainly prefer the shops located in the suburbs. Also in Teramo the urban trade has to face deep problems following the earthquakes of 2016 and 2017 (Cardinale, Matani 2019, 123).

At present, there is a big gap between the main inland cities, where modern retailing has spread, and the remaining part of inland Abruzzo, where small independent retailing is still present and has to cope with great difficulties due to low accessibility, loss of custom-

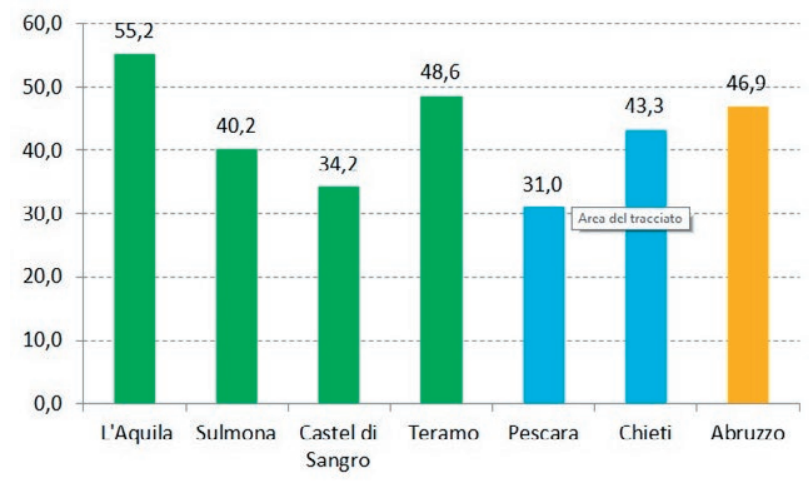

Figure 1. Inhabitants per trade firm in the selected cities and Abruzzo. Year 2017. Source: author's elaboration on data from ISTAT Censuses and ISTAT ASIA Archive. ers following the population decrease and limited retail supply, so that a real risk of rarefaction of trade firms reasonably exists. In this respect, the consequences of the Covid-19 pandemic may be lethal for the retail structure of such smaller communities, if not supported by adequate place-sensitive policies (Di Matteo 2021).

\section{Retailers' perception and local policies: inland vs. coastal cities}

The need to explore and update the knowledge about the spatial distribution of the shops, the behaviour of trade operators and, broadly, the urban retail

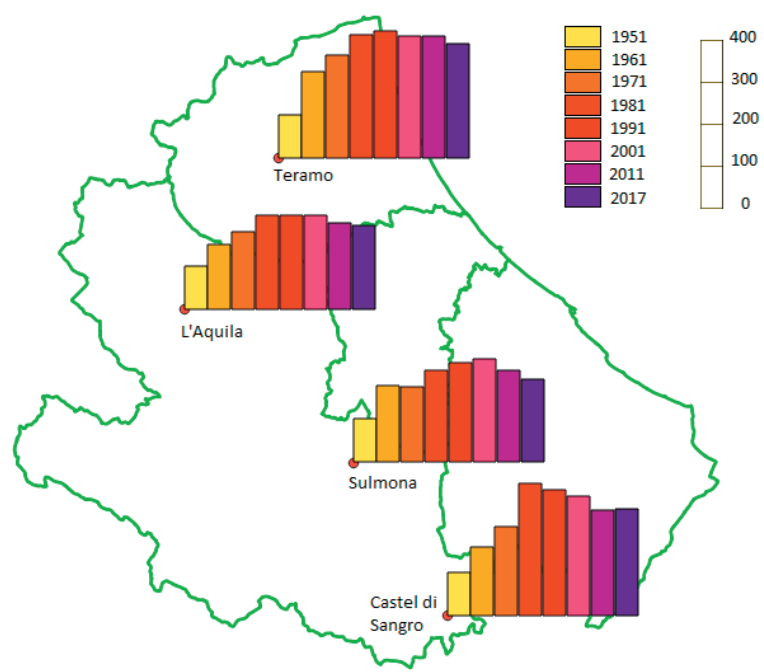

Figure 2. Trade firms in the selected cities. Years 1951-2017 $(1951=100)$. Source: author's elaboration on data from ISTAT Censuses and ISTAT ASIA Archive. 
dynamics is a longstanding objective for geographers (Warnes, Daniel 1980). The retail geography is an articulation of processes involving various material and immaterial dimensions, resulting in a combination of "places, spaces and practices [that] are never purely economic" (Lowe, Wrigley 2000, 641-642), thus implying the need for a specific deepening from the point of view of the operators and their perception. The retailers operate in a competitive space that fosters the establishment of a series of regulatory domains, such as land-use and environmental planning, food law and safety, crime and social order (Marsden et al. 1998, 482 ), and at the aim to regulate these issues suitable policies from governmental bodies are required. The mutual relation between local governments and retailers' supply lies in the reason that the "retailers [constantly deal] with consumers [so far as to] become sensitive barometers for government in the testing of what is seen to be legitimate policy" (ivi, p. 489).

For such purposes, it is therefore necessary to explore the perception of local operators about some of the most common policies carried out by governmental bodies, and this will help understand which are the policies that enhance the retailers' overall perception and which, otherwise, still represent weaknesses in the retail processes of the inland cities of Abruzzo region. Data coming from a survey conducted among some inland and coastal cities in Abruzzo provided us some information related to the degree of improvement of retail activities and a series of observations regarding the evaluation of some main policies undertaken by local institutions, in the opinion of the retailers. These data have been put in correlation through the principle individuated by Charles Spearman (1904, p. 77), which is summarised in the following formula:

$r=\frac{S x y}{\sqrt{S x^{2} \times S y^{2}}}$ where $r$ is the required correlation, $x$ and $y$ are the deviation of any pair of characteristics from their mean and $S x y$ is their sum, $S x^{2}$ and $S y^{2}$ are the sum of the squares of all the values of $x$ and $y$. The choice of the Spearman correlation instead of the Pearson one is due to the (ordinal) rank feature of the collected variables, and for this reason a non-parametric and non-linear approach like the Spearman's rank correlation has been regarded as preferable, in particular because its use is recognised in geographical studies who consider different administrative territories as part of the correlation analysis (Hauke, Kossowski 2011, 89). The results are presented in the table 2 .

On the whole, both separately and as a unique proxy of the inland areas, the majority of the policies adopted by the inland municipalities seem to be positively correlated with the general perception of the retailers. In particular, the policy related to the trade valorisation carried out through direct initiatives of the public institutions is significantly correlated with the perception of the retailers of L'Aquila $(0.473, p<0.05)$ and Teramo $(0.558$, $p<0.05)$, while the correlation is less significant in the case of Castel di Sangro $(0.394, p<0.10)$ but still positive; the urban policies related to the improvement of accessibility and pedestrianisation appear to be positively and significantly correlated only with the perception of the retailers of Teramo $(0.436, p<0.05 ; 0.390, p<0.05)$ and Castel di Sangro $(0.478, p<0.05 ; 0.447, p<0.05)$; the policy concerning the urban furniture seems to be an element which positively influences the perception of the retailers, boosting the degree of improvement of the commercial activities in the case of Teramo (0.537, $p<0.05)$, Castel di Sangro $(0.458, p<0.05)$ and L'Aquila $(0.289, p<0.05)$; the advertising valorisation of commercial activities generates positive and highly significant correlation with the perception of Teramo's $(0.574, p<0.05)$ and L'Aquila's $(0.427, p<0.05)$ retailers, while the significance is lower in Castel di Sangro (0.442, $p<0.10)$; similarly, the policy con-

Table 2. Correlation between local trade perception and types of policies. Source: author's elaboration on survey data; Spearman correlation is reported, ${ }^{* *}$ indicates significance at $\mathrm{p}<0.05,{ }^{*}$ indicates significance at $\mathrm{p}<0.10$

\begin{tabular}{lcccccc}
\hline city/type of policy & L'Aquila & Sulmona & Teramo & Castel di Sangro & Inland Cities & Coastal Cities \\
\hline $\begin{array}{l}\text { Trade valorisation by public } \\
\text { institutions }\end{array}$ & $0.473^{* *}$ & -0.240 & $0.558^{* *}$ & $0.394^{*}$ & $0.434^{* *}$ & $0.414^{* *}$ \\
Accessibility & 0.143 & 0.163 & $0.436^{* *}$ & $0.478^{\star *}$ & $0.241^{* *}$ & $0.354^{* *}$ \\
Pedestrianisation & 0.165 & 0.033 & $0.390^{* *}$ & $0.447^{* *}$ & $0.236^{* *}$ & 0.107 \\
Urban furniture & $0.289^{* *}$ & 0.225 & $0.537^{* *}$ & $0.458^{\star *}$ & $0.351^{* *}$ & $0.310^{* *}$ \\
Advertising valorisation & $0.420^{* *}$ & -0.110 & $0.574^{* *}$ & $0.442^{*}$ & $0.352^{* *}$ & $0.333^{* *}$ \\
Public subsides & $0.427^{* *}$ & -0.083 & $0.557^{* *}$ & $0.420^{*}$ & $0.429^{* *}$ & $0.367^{* *}$ \\
observations & 50 & 24 & 52 & 20 & 146 & 155
\end{tabular}


cerning public incentives to the retailers' activities shows a good and highly significant correlation in the case of Teramo $(0.557, p<0.05)$ and L'Aquila $(0.427, p<0.05)$, while it is positive but less significant for the retailers of Castel di Sangro $(0.420, p<0.10)$.

It is immediately clear that the perception of Sulmona's retailers shows correlations with none of the abovementioned public policies. This could lead to a diachronic understanding of the data: on the one hand, it is possible that trade and commercial activities of the retailers of Sulmona are so good that they do not require any type of intervention; on the other, it may suggest that the trade activities in Sulmona are close to the stagnation phase of its logistic life-cycle curve, which makes any kind of policy irrelevant.

If we consider the four municipalities as a whole proxy of the inland cities of Abruzzo region, we observe analogies and differences with the other proxy regarding the coastal cities (proxied by the cities of Pescara and Chieti). Policies like trade (0.434 vs 0.414$)$ and advertise (0.352 vs 0.333$)$ valorisation by institutions and urban furniture (0.351 vs 0.310$)$ show very similar coefficients both for inland and for coastal cities; accessibility policy towards urban areas seems to be more successful in coastal cities ( 0.354 vs 0.241$)$, probably thanks to the better conditions of the arterial roads; conversely, public subsides programs seem to generate higher and positive correlation with the retailers of inland cities $(0.429$ vs 0.367$)$, presumably because the retailers located in peripheral areas have benefited from greater public incentives for their activity; lastly, policies related to the pedestrianisation show significant coefficients only in the case of inland cities, probably because of the higher degree of urbanisation of retail shops located near the coastal cities, which do not require adjustments to pedestrianisation.

\section{Planning for a retail resilience: who needs more?}

A good retail planning system may influence the resilience of a community, where retail areas may "be part of a structure enabling resilient everyday life" (Rao, Summers 2016, 98). Despite the private nature of the retail sector, planning and public policies for retail development have always been a guidance and a regulator whenever the fluid scenario of the retailing system has altered its spatial equilibrium, thus moving from city centres to suburbs and shopping centres and then evolving again in other types of retail spaces (Fernandes, Chamusca 2014). It is a mutual cooperation between retailers and local governments: specific location decisions of private individuals may help public authorities to regenerate and make resilient a certain area in the urban space; vice-versa, public policies, such as incentives towards certain categories of products, may encourage the flourishing of a diversified and targeted commercial portfolio for the city, as well as the possibility to start up new businesses for private individuals.

On the basis of the available data, we propose regression models in which we post-estimate the predictive margins regarding four specific characteristics of the interviewed retailers in Abruzzo inland areas. The baseline model takes the following formula:

$y=\beta_{0}+\sum \beta_{n} X_{n}+R_{i}+\varepsilon_{i}$

where $y$ is the outcome variable expressed by retailers' perception about the commercial evolution of the area, $\Sigma \beta_{n} X_{n}$ is a set of control covariates shaped on the same types of public policies used in (1), $R_{i}$ is the (ordinal) rank variable used as main predictor of retailers' perception and consisting in certain features measured in the survey, $\varepsilon_{i}$ is an error term. Afterwards, follow-

Table 3. Adjusted predictive margins of retailers' main features. Source: author's elaboration on survey data; delta-method standard errors are in parentheses; ${ }^{* *}$ indicates significance at $\mathrm{p}<0.01$; all predictors are at their mean value; the numerousness (146) encompasses the observations collected for the four inland cities as a whole territorial system

\begin{tabular}{|c|c|c|c|c|c|c|c|}
\hline Years in business & Margin & Type of business & Margin & $\begin{array}{l}\text { Trust and loyalty } \\
\text { relevance }\end{array}$ & Margin & Shop size (sqm) & Margin \\
\hline$<10$ & $\begin{array}{l}1.773^{* * *} \\
(0.0754)\end{array}$ & self-employed & $\begin{array}{l}1.834^{\star * *} \\
(0.0559)\end{array}$ & for nothing & $\begin{array}{l}1.610^{* * *} \\
(0.5653)\end{array}$ & $<50$ & $\begin{array}{l}1.829^{* * *} \\
(0.0712)\end{array}$ \\
\hline $11-20$ & $\begin{array}{l}1.856^{* * *} \\
(0.0949)\end{array}$ & $\begin{array}{c}\text { head office of a } \\
\text { chain }\end{array}$ & $\begin{array}{l}1.596^{* * *} \\
(0.2322)\end{array}$ & somewhat low & $\begin{array}{l}1.693^{* * *} \\
(0.1467)\end{array}$ & $51-100$ & $\begin{array}{l}1.882^{* * *} \\
(0.0750)\end{array}$ \\
\hline $21-30$ & $\begin{array}{l}1.885^{* * *} \\
(0.1222)\end{array}$ & branch of a chain & $\begin{array}{l}1.921^{\star * *} \\
(0.1425)\end{array}$ & somewhat high & $\begin{array}{l}1.746^{* * *} \\
(0.0895)\end{array}$ & $101-200$ & $\begin{array}{l}1.974^{* * *} \\
(0.1757)\end{array}$ \\
\hline$>30$ & $\begin{array}{l}2.035^{\star * *} \\
(0.1102)\end{array}$ & franchise & $\begin{array}{l}2.042^{* * *} \\
(0.1292)\end{array}$ & totally & $\begin{array}{l}1.951^{* * *} \\
(0.0609)\end{array}$ & $>200$ & $\begin{array}{l}1.769^{* * *} \\
(0.2949)\end{array}$ \\
\hline
\end{tabular}


ing the interpretation of Honoré $(2008$, p. 6) about the potentiality of $\beta$ to calculate interesting marginal effects "even when the errors in the model and the explanatory variables are not independent", we compute the adjusted predictive margins for four observed characteristics $\left(R_{i}\right)$ : a) number of years in business; $b$ ) type of business; $c$ ) trust and loyalty relevance with the consumers; $d$ ) shop size.

The results of the postestimations provided in Tab. 3 show the coefficients of the predictive margins for each rank of the involved ordinal variables. This procedure helps us to individuate, although summarily, which classes of retailers need priority interventions by local governments of inland areas of Abruzzo and which, on the contrary, already have satisfactory performances. The results may be useful for addressing retail development policies in such places. An easier display of the coefficients is provided in the following figure.
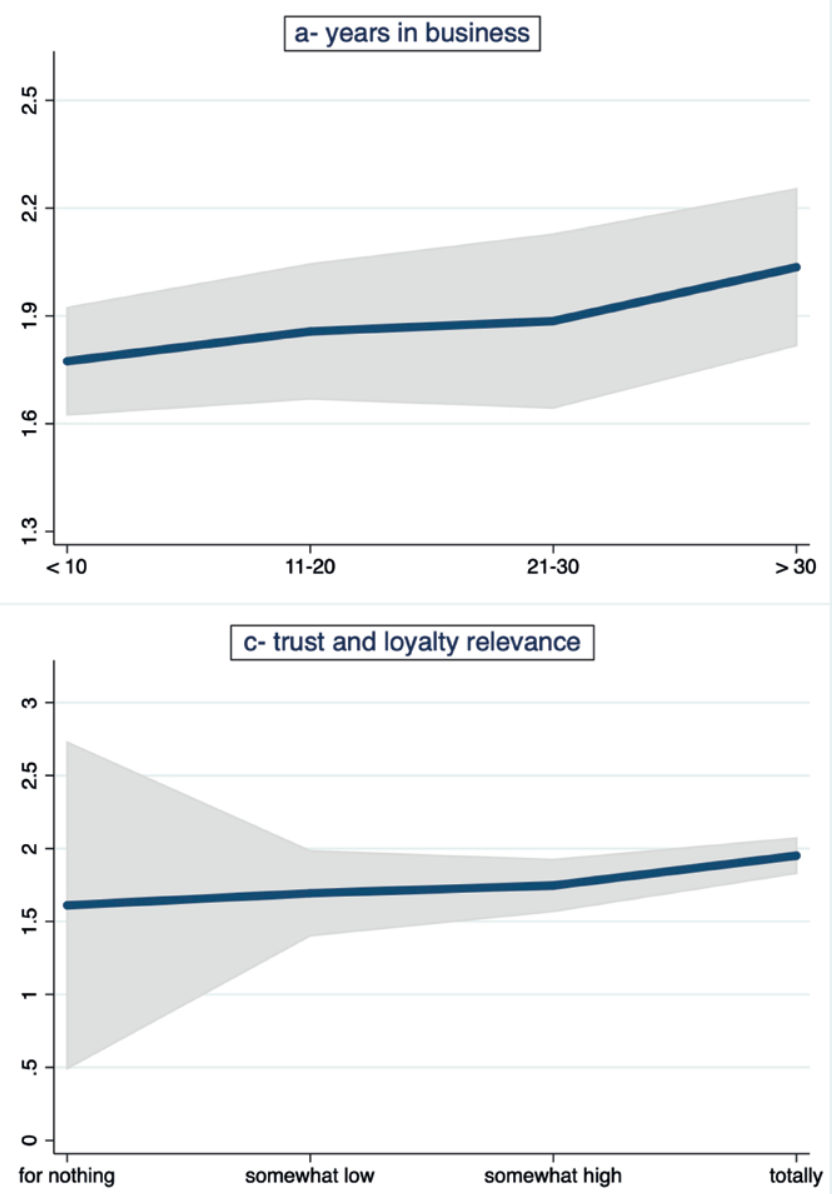

When the number of years in business is considered, we observe a regular confidence interval for all the four typologies; anyway, retail shops with 21-30 years and in particular - those with more of 30 years in business seem to be more positive towards the degree of retail development of their city, while retailers with less years of business show lower values. As concerns the type of business, more positive perception is observed for shops in franchise or for branches of a chain; probably this value reflects lesser responsibilities of these two types of businesses compared to the obligations, deadlines and management implications of self-employed shops and head shops/offices of a chain.

As far as the parameter of trust and loyalty relevance between retailers and consumers is concerned, shops that consider it highly relevant or relevant are generally more positive towards the retail development of their area, while shops that give low or zero relevance to
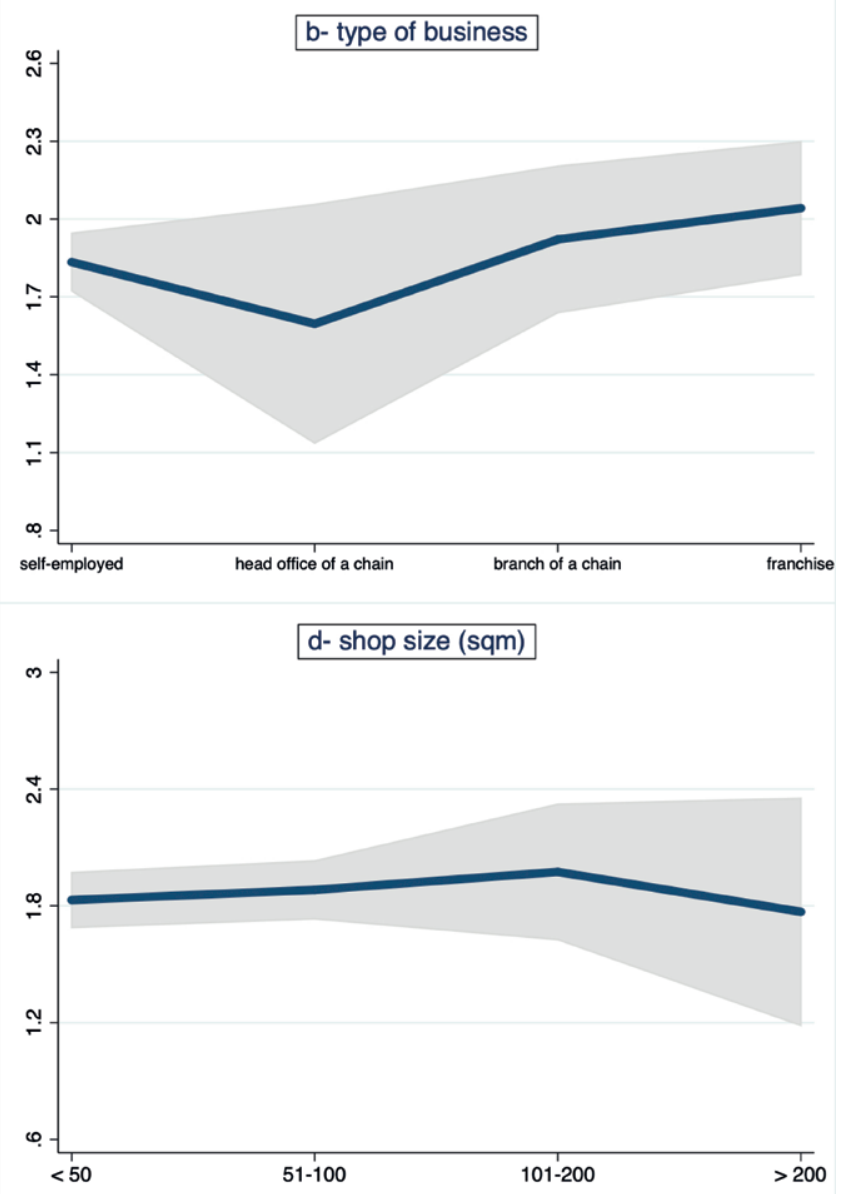

Figure 3 (a-b-c-d). Graphical adjusted predictive margins of retailers' main features. Source: author's elaboration; the grey shadows represent the confidence interval areas at $95 \%$ of confidence level. 
trust and loyalty seem to have poorer perception about the retail health status of their area. Lastly, small $(<50$ sqm) and medium-small (51-100 sqm) shops seem to be the ones with the best perception, while bigger shops show a not suitable confidence interval: it probably means that they perceive less positively the retail environment of their area. This probably reflects the longterm change in the commercial structure of Abruzzo, where wholesale shops have progressively given way to smaller retailers.

These results may suggest some early indications for addressing future policies: from the retailers' perspective, they need to give more emphasis on their relationship with the consumers in terms of trust and loyalty because high relevance in this mutual cooperation generates a better retail development; local governments, instead, should primarily focus on the newer shops (less than 20 years in business), with targeted interventions towards self-employed shops and head shops of a chain, taking into account those shops that need a wide space to carry on their activities.

\section{Buying behaviour and perception: a survey}

In recent decades many authors have faced a new sociological category: the "post-modern" consumer, that is, a new type of consumer who expresses his/her identity through purchase decisions (Featherstone 1991). According to Fabris (2003), the post-modern consumer is syncretic, since he/she embodies different lifestyles, and eclectic, because he/she combines heterogeneous cultural features. For Gilles (2007) he/she is well informed and seeking for quality. His/her purchase decisions are also a way of asserting political ideas (Graziano, Forno 2012). Essentially, buying behaviour has nowadays social and cultural functions that go beyond the needs of everyday life (Paltrinieri 2004; Hamouda 2012) and can give relevant information from a geographical point of view as well (Berry 2013; Montello 2018).

Keeping these assumptions in mind, in the spring of 2018 a survey has been conducted via face-to-face interviews to a sample of 625 individuals visiting historic city centres and shopping malls in three coastal cities (Pescara, 200 units; Chieti, 100 units; Lanciano, 50 units) and four inland cities (L'Aquila, 100 units; Teramo, 100 units; Sulmona, 50 units; Castel di Sangro, 25 units). In this Section, the main findings of the survey will be discussed. In particular, the divergences between the two groups (coastal cities and inland cities) in the buying behaviour and perception of the interviewees will be reported, in order to get some indication if, and to what extent, different purchase patterns can be related to different geographical situations.

The first thing to underline is that there are no significant differences between the two groups as to the main reason for reaching the place where the interviews occurred (Tab. 4). For most of the respondents of both groups it is one of the following: "shopping", "workplace", "stroll", "restaurants/bars". The only noteworthy divergences refer to "attractiveness of brands" and "environment/atmosphere", which are relatively more important for visitors of inland cities.

"Clothing/footwear" and "foodstuffs" are by far the main items of interest for both groups, but in inverted proportions: the interviewees of coastal cities favor clothing and footwear, while those of inland cities mostly buy foodstuffs (Tab. 5).

The visitors of inland cities show a very positive perception of the area where the interview took place, since $85 \%$ of them judge its atmosphere pleasant or very pleasant, which is consistent with the results of table 4. Not as enthusiastic, but still favourable, is the assessment of the visitors of coastal cities $(67,9 \%)$. On the contrary, the latter give greater importance to the relationship of trust and loyalty with the shopkeeper $(83,5 \%$, against $64 \%$ of the former), showing some kind of "nostalgic" attitude as well, since $45,2 \%$ of them think that the importance of this relationship has decreased during the past 10 years.

There are no major differences on the mobility side either (Tab. 6). About half of the interviewees of both groups reached the place of the interview by car. To get there on foot is slightly more common among visitors of inland cities, while those of coastal cities are relatively more inclined to use urban transportation. The acces-

Table 4. What is the main reason to come to this place? (\%). Source: author's elaboration on survey data.

\begin{tabular}{lccc}
\hline & $\begin{array}{c}\text { total } \\
\text { sample }\end{array}$ & $\begin{array}{c}\text { coastal } \\
\text { cities }\end{array}$ & $\begin{array}{c}\text { inland } \\
\text { cities }\end{array}$ \\
\hline shopping & 29,4 & 30 & 28,7 \\
workplace & 18,1 & 20,8 & 14,5 \\
stroll & 16,3 & 16,3 & 16,4 \\
restaurants/bars & 13,6 & 15,7 & 10,9 \\
private matters & 7,8 & 6,8 & 9,2 \\
education/training & 4,0 & 4,6 & 3,3 \\
crossing to reach other places & 3,7 & 2,9 & 4,7 \\
attractiveness of brands & 2,6 & 0,6 & 5,1 \\
cinemas/theatres/exhibits/sport & 2,2 & 1,7 & 2,9 \\
environment/atmosphere & 1,6 & 0 & 3,6 \\
others & 0,6 & 0,6 & 0,7
\end{tabular}


Table 5. What kind of goods are you interested in when you come to this place? (\%). (Only to those who answered "shopping" to the first question). Source: author's elaboration on survey data.

\begin{tabular}{lccc}
\hline & $\begin{array}{c}\text { total } \\
\text { sample }\end{array}$ & $\begin{array}{c}\text { coastal } \\
\text { cities }\end{array}$ & $\begin{array}{c}\text { inland } \\
\text { cities }\end{array}$ \\
\hline clothing, footwear & 43,1 & 53,5 & 28,7 \\
foodstuffs & 34,8 & 26,7 & 46,1 \\
sportswear & 4,3 & 3,1 & 6,1 \\
books, stationery & 3,6 & 4,3 & 2,6 \\
electronics & 3,3 & 3,1 & 3,5 \\
perfumery items & 2,5 & 1,9 & 3,5 \\
jewelry, watches & 1,8 & 2,5 & 0,9 \\
telephony items & 1,4 & 1,2 & 1,7 \\
furniture & 1,4 & 1,9 & 0,9 \\
household products & 1,4 & 1,2 & 1,7 \\
others & 2,2 & 0,6 & 4,3 \\
\hline
\end{tabular}

sibility of the place of the interview, on the other hand, is perceived in more positive terms by the visitors of the inland cities: $82,7 \%$ of them judge it good or very good, against $63,2 \%$ of the other group.

Pedestrianisation is a quite interesting issue: it is definitely more common in coastal cities $(63,5 \%$ of occurrences against 35\%); but it is intriguing to note that, while almost all the respondents of the cities with no pedestrian area would not be in favour of creating one, very few respondents of the cities where a pedestrian area exists (that is, the three coastal cities plus Teramo) would support its elimination.

Finally, $68 \%$ of visitors of coastal cities believe that malls are causing the closure of shops in historic city centres, against the $36 \%$ of the other group, where this trend is less present or less perceived (Tab. 7).

In conclusion, according to the findings of the survey it seems that the buying behaviour and the perception of the interviewees do not change very much from

Table 6. How did you get here? (\%). Source: author's elaboration on survey data.

\begin{tabular}{lccc}
\hline & $\begin{array}{c}\text { total } \\
\text { sample }\end{array}$ & $\begin{array}{c}\text { coastal } \\
\text { cities }\end{array}$ & $\begin{array}{c}\text { inland } \\
\text { cities }\end{array}$ \\
\hline car & 49,6 & 49,7 & 49,4 \\
on foot & 26,4 & 24,3 & 29.1 \\
city bus & 7,5 & 9,4 & 5,1 \\
bicycle & 7,4 & 8,3 & 6,2 \\
motorcycle & 5,4 & 6 & 4,7 \\
suburban bus & 3,2 & 2,3 & 4,4 \\
train & 0,5 & 0 & 1,1 \\
\hline
\end{tabular}

Table 7. How much do you agree with the following statement? "Malls are causing the shops in the historic city centres to close" (\%). Source: author's elaboration on survey data.

\begin{tabular}{lccc}
\hline & $\begin{array}{c}\text { total } \\
\text { sample }\end{array}$ & $\begin{array}{c}\text { coastal } \\
\text { cities }\end{array}$ & $\begin{array}{c}\text { inland } \\
\text { cities }\end{array}$ \\
\hline strongly agree & 23,2 & 27,7 & 17,5 \\
agree & 30,7 & 40,3 & 18,5 \\
neither agree nor disagree & 28,5 & 24 & 34,2 \\
disagree & 13,0 & 7,4 & 20,0 \\
strongly disagree & 4,6 & 0,6 & 9,8 \\
\hline
\end{tabular}

coastal to inland cities, despite gaps in terms of functions, demographic size and accessibility. The divergences, where present, are not substantial, being limited to the intensity with which some features and trends are perceived, or to secondary issues. The phenomenon of homogenisation of lifestyles and buying behaviour, due to the rapid development of communication systems and the convergence towards consumption standards, is well known since a long time: "the world's needs and desires have been irrevocably homogenized" (Levitt 1983, 93). The findings of the survey seem to be in line with this assertion.

\section{Conclusions}

The social and economic evolution of Abruzzo has often traveled along a double track, which reflects the identity ambivalence of this region: coastal and inland, Adriatic and Apennine, urban and rural. A dichotomy was also observed in the evolution of urban trade: the decline of the last decade was felt slightly in the major urban areas, while smaller settlements, especially those of the inland, were more affected due to demographic weakness and scarce infrastructure (Fuschi, Ferrari 2019). In this paper we have focused on the inland part of the region, in its comparison with the coastal area. In particular, we referred to an aggregate consisting of four inland cities: L'Aquila, Teramo, Sulmona and Castel di Sangro. They are at the same time heterogeneous in terms of size, accessibility and functions, and comparable in their retail dynamics, so as to be considered representative of the sub-regional unit under investigation.

In the first decades of the second post-war period, the retail trade in Abruzzo was rather pulverised due to its role of a safe-haven sector for unoccupied workforce, not yet absorbed by industry. In inland areas, this phenomenon was even stronger: the highly scattered localisation of the retail firms was required by the scarce 
mobility of the population, due in turn to deficiencies in transportation and accessibility. It must also be said that, despite the small size and the poor propensity to innovation, the traditional and family-run retail firms used to play a fundamental role in protecting the minimum level of quality of life and the satisfaction of the basic needs of the inhabitants.

The trade reform introduced in 1971, which fostered modern distribution with department stores and supermarkets, gave rise to a two-speed growth of the trade: while in coastal areas, thanks to greater economic and demographic vitality, modernisation started earlier, continued quickly and had significant effects, in inland areas it showed up later and developed more slowly; furthermore, its effects were limited and concentrated in the main cities (L'Aquila, Sulmona, Teramo), which were emerging as demographic and industrial poles.

Currently there is a deep gap between the main inland cities, whose retail network has finally modernised, as evidenced by the opening of important shopping centres, and the rest of inland Abruzzo, where a prevailing fabric of small independent retailers faces great difficulties due to poor accessibility, loss of customers as a result of population decline, and limited supply, so that there is a real risk of rarefaction of retail firms. To all this must be added the general difficulties of traditional retail due to the economic crisis and the competition from modern specialised shops and online commerce, together with the unexpected health emergency caused by the Covid-19 pandemic. The case of L'Aquila is noteworthy: the 2009 earthquake and the consequent relocation of many retail firms to shopping centers and galleries produced a real push to malling, given the role that the latter have ended up taking as poles of social aggregation.

The spatial distribution of the shops and the urban retail dynamics can be usefully related to the perception that local operators have about the policies implemented by governmental bodies, in order to understand which are the policies that enhance the retailers' overall perception and which, otherwise, still represent weaknesses in the retail processes. For these purposes, we have used data coming from a survey conducted in 2018 among some inland and coastal cities of Abruzzo that provided us information about the improvement of retail activities and the opinion of the retailers regarding the evaluation of the policies undertaken by local institutions.

According to the findings of the non-parametric modeling, it seems that the retail sector of inland Abruzzo does not travel at a very different speed than that of coastal areas. What can be inferred, instead, is that the former has more utilitarian and resilient features, with a stronger view to serving the community, compared to the more hedonistic and consumerist ways that can be observed in the major coastal cities. The survey also showed that newer stores, as well as those run by the owner himself, appear to be more vulnerable to trade fluctuations than the long-lasting ones, making it necessary to have consequent and specific public policies and plans, which are supposed to be more place-sensitive (Di Matteo 2021).

On the demand side, buying behaviour and perception of the consumers can give relevant information as well. Therefore, a parallel survey has been conducted in the same inland and coastal cities via face-to-face interviews to visitors and customers, in order to get some indication if, and to what extent, different purchase patterns can be related to different geographical situations. The findings show that there are no major differences between the two groups (inland and coastal) of interviewees in most of the aspects considered by the survey. The divergences, where present, are not substantial, being limited to the intensity with which some features and trends are perceived, or to secondary issues.

Therefore, it seems that both on the supply and the demand sides behaviour and perception of the individuals do not change very much from coast to inland, despite gaps in terms of functions, demographic size, accessibility, spatial distribution of shops and structural organisation of retail. To quote Levitt (1983), we can conclude that the findings of the surveys seem to be in line with his assertion that the "needs and desires of the people underwent in the last decades a process of homogeneisation worldwide".

\section{References}

Berry, B.J.L. (2013). Commercial and Economic Geography: Past and Future. In Garrocho, C. (Ed.). Advances in Commercial Geography. Prospects, Methods and Applications. Zinacantepec, El Colegio Mexiquense, 43-58.

Borchert, J.G. (1988). Window on Netherlands Recent Developments in Retailing in the Netherlands. Tijdschrift voor Economische en Sociale Geografie, 79 (3), 220-226.

Brunetta, G. (2007). Geografia delle localizzazioni commerciali e sistemi di regolazione e valutazione in Piemonte. Ciudades, 10, 97-107.

Brunetta, G. (Ed.) (2011). Classificazione e interpretazione di sistemi territoriali d'offerta commerciale in Piemonte. Un approfondimento nei territori dei distretti commerciali, Turin, Polytechnic University of Turin. 
Brunetta, G., Caldarice, O. (2016). Retail Planning for Regional Development: The Design of Resilient Scenarios in Trentino (Italy). Journal of Civil Engineering and Architecture, 10, 1173-1182

Cannizzaro, S. (2019), La diffusione di nuovi modelli distributivi in Sicilia e la moderna funzione del commercio nelle Città metropolitane. In Cusimano, G. (Ed.). Le strade del commercio in Sicilia. Milan, Angeli, 205-219.

Cardinale, B., Matani, L. (2019). Il paesaggio urbano e gli spazi commerciali di Teramo. Un rapporto imprescindibile tra resilienze e politiche urbane. In Fuschi, M., Ferrari, F. (Eds.). Commercio e consumo nelle città d'Abruzzo. Casi studio. Milan, Angeli, 117-141.

Clerici, M.A. (2019). Competere nel commercio. Milano e le città medie tra deregulation e grande recessione. Milan, Angeli.

Cozzi, S. (2006). La distribuzione commerciale in Italia: caratteristiche strutturali e tendenze evolutive. Contributi Istat series 2006/8. Rome, Istat.

Di Matteo, D. (2021). Effectiveness of Place-sensitive Policies in Tourism. Annals of Tourism Research, 103146, https://doi.org/10.1016/j.annals.2021.103146

Fabris, G. (2003). Il nuovo consumatore: verso il postmoderno. Milan, Angeli.

Featherstone, M. (1991). Consumer Culture and Postmodernism. London, Sage.

Fernandes, J.R., Chamusca, P. (2014). Urban Policies, Planning and Retail Resilience. Cities, 36, 170-177.

Fuschi, M., Ferrari, F. (2019). Città, commercio, consumo: la nuova geografia commerciale nelle principali città d'Abruzzo. In Fuschi, M., Ferrari, F. (Eds). Commercio e consumo nelle città d'Abruzzo. Casi studio. Milan, Angeli, 7-33.

Gilles, L. (2007). Una felicità paradossale. Sulla società dell'iperconsumo. Milan, Cortina.

Giraldo Lozano, L.P. (2015). Configuraciones espaciales del comercio minorista en Brasil. Geograficando, 11 (2), 1-17.

Graziano, P.R., Forno, F. (2012). Political Consumerism and New Forms of Political Participation. The Annals of the American Academy of Political and Social Science, 644 (1), 121-133.

Hallsworth, A.G. (1994). Decentralization of Retailing in Britain: The Breaking of the Third Wave. The Professional Geographer, 46 (3), 296-307.
Hamouda, M. (2012). Postmodernism and Consumer Psychology: Transformation or Break? International Journal of Academic Research in Business and Social Sciences, 2 (1), 96-117.

Hauke, J., Kossowski, T. (2011). Comparison of Values of Pearson's and Spearman's Correlation Coefficients on the Same Sets of Data. Quaestiones Geographicae, 30 (2), 87-93.

Honoré, B.E. (2008). On Marginal Effects in Semiparametric Censored Regression Models. SSRN, DOI:10.2139/ ssrn. 1394384

Landini, P. (1981). Caratteri geografici del terziario commerciale in Italia. Bollettino della Società Geografica Italiana, X, IX, 11-46.

Levitt, T. (1983). The Globalization of Markets. Harward Business Review, May-June, 92-102.

Lowe, M., Wrigley, N. (2000). Retail and the Urban. Urban Geography, 21 (7), 640-653.

Marsden, T., Harrison, M., Flynn, A. (1998). Creating Competitive Space: Exploring the Social and Political Maintenance of Retail Power. Environment and Planning A: Economy and Space, 30 (3), 481-498.

Montello, D.R. (2018). Behavioral and Cognitive Geography: Introduction and Overview. In Montello, D.R. (Ed). Handbook of Behavioral and Cognitive Geography. Cheltenham, Edward Elgar Publishing Ltd.

Morandi, C., Paris, M. (2013). From Retail Polarities to Superplaces New Tools to Undestand Recent Transfomations in Retail Geography in Italy: The Assago (Mi) Case. Revista Lusófona de Arquitectura e Educação, 8-9, 427448.

Musso, F. (2007). La modernizzazione del commercio fra centri storici ed entroterra rurale. I cambiamenti della distribuzione al dettaglio nella provincia di Pesaro Urbino. Urbino, Argalia.

Musso, F. (2010). Small Retailing, Town Centres and Inland Territories. An "Extended Town Centre Management" Perspective. Public Administration \& Regional Studies, 2 (6), 37-58.

Paltrinieri, R. (2004). Consumi e globalizzazione. Rome, Carocci.

Pascetta, C. (2019). La resilienza urbana dopo lo shock: geografia del commercio e del consumo a L'Aquila a dieci anni dal terremoto. In Fuschi, M., Ferrari, F. (Eds.). Commercio e consumo nelle città d'Abruzzo. Casi studio. Milan, Angeli, 35-74. 
Porto, C.M. (2019). Spazi del consumo, gerarchie commerciali e processi di territorializzazione nelle Marche policentriche. In Nicosia, E., Porto, C.M., Graziano, T. (Eds.). Il commercio nelle aree urbane marchigiane tra vecchi e nuovi format. Milan, Angeli, 115-160.

Preite, M. (2005). La riqualificazione e il rilancio del commercio al dettaglio nelle aree di montagna: nuove strategie di intervento nell'Amiata grossetano. In Adobati, F., Oliveri, A., Tamini, L. (Eds.). Commercio e politiche territoriali: 4 temi emergenti. Bergamo, Sestante.

Rao, F., Summers, R.J. (2016). Planning for Retail Resilience: Comparing Edmonton and Portland. Cities, 58, 97-106.

Scorrano, S. (1997). Il terziario commerciale abruzzese tra marginalità e innovazione. Bollettino della Società Geografica Italiana, 1-2, 177-204.

Sinha, P.K., Kar, S.K. (2009). Insights into the Growth of New Retail Formats in India. In Krafft, M., Mantrala, M.K. (Eds.). Retailing in the 21st Century - Current and Future Trends. Berlin Heidelberg, Springer-Verlag, 119140.

Spearman, C. (1904). The Proof and Measurement of Association Between Two Things. The American Journal of Psychology, 15 (1), 72-101.

Szczyrba, Z. (2010). Development of Retail Geographical Structure in the Czech Republic: A Contribution to the Study of Urban Environment Changes. Acta Universitatis Palackianae Olomucensis - Geographica, 41 (2), 5-20.

Warnes, A.M., Daniels, P.W. (1980). Urban Retail Distributions: An Appraisal of the Empirical Foundations of Retail Geography. Geoforum, 11 (2), 133-146. 